\title{
Effect of Different Sources of Phosphate Fertilizers on Cadmium Accumulation in Potato Tubers (Solanum tuberosum L.) in the Calcareous Soils of Iran
}

\author{
Karimi H', Malakouti MJ ${ }^{2}$, Davari $\mathbf{M}^{3}$ and \\ Asbaghian SKh ${ }^{1 *}$ \\ ${ }^{1}$ Graduate Student, Department of Soil Science, Tarbiat \\ Modares University, Tehran, Iran \\ ${ }^{2}$ Professor, Department of Soil Science, Tarbiat Modares \\ University, Tehran, Iran \\ ${ }^{3}$ Assistant Professor, Department of Soil Science, Faculty \\ of Agriculture, University of Kurdistan, Iran \\ *Corresponding author: Asbaghian SKh, Graduate \\ Student, Department of Soil Science, Tarbiat Modares \\ University, Tehran, Iran
}

Received: October 22, 2021; Accepted: November 15, 2021; Published: November 22, 2021

\begin{abstract}
Potato (Solanum tuberosum L.) is the fourth most important agricultural crop after wheat, rice, and maize around the world, so increasing its quality (with a low amount of contaminants) is very important and notable. If for any reason, Cadmium (Cd) concentration increases in the soil, its uptake by the potato will be increased as a result. One of the main sources of $\mathrm{Cd}$ in the soil is the application of imbalanced fertilization especially consuming imported phosphate fertilizers. In order to investigate the effect of different sources of P-fertilizers on the $\mathrm{Cd}$ accumulation in potato tubers, an experiment was carried out on a farm in Dehgolan, Iran. This experiment was conducted based on a Randomized Complete Block Design (RCBD) with three replications. Before starting the experiment, soil and P-fertilizer samples were taken and analyzed in the laboratory. The concentration of soil available $\mathrm{P}, \mathrm{Zn}$, and $\mathrm{Cd}$ were 8.0, 0.75 , and $0.15 \mathrm{mg} \mathrm{kg}^{-1}$ respectively and the concentration of $\mathrm{Cd}$ in different P-fertilizers were 5, 15, and $25 \mathrm{mg} \mathrm{kg}^{-1}$ respectively. Experimental treatments were: $\mathrm{T}_{1}$ (control) $=$ Without $\mathrm{P} ; \mathrm{T}_{2}=\mathrm{T} 1+\mathrm{RP}$ (Rock Phosphate); $\mathrm{T}_{3}=\mathrm{T}_{1}+\mathrm{SSP}$ (Simple superphosphate) and $\mathrm{T}_{4}=\mathrm{T}_{1}+\mathrm{TSP}$ (Triple superphosphate). The results revealed that Cd concentration in $T_{1}$ was 0.10 , in $T_{2}$ was 0.13 , in $T_{3}$ was 0.25 and in $\mathrm{T}_{4}$ was $0.29 \mathrm{mg} \mathrm{kg}^{-1}$. Thus, TSP caused maximum, and RP caused the least $\mathrm{Cd}$ accumulation in potato tubers $(p<0.01)$. According to the obtained results, it can be concluded that application of P-fertilizers should be based on the soil test results and using rock phosphate and simple superphosphate should become a priority, we have to select P-fertilizers which has the lowest Cd concentration, and to take care of controlling the quality of imported P-fertilizers especially their Cd content.
\end{abstract}

Keywords: Potato (Solanum tuberosum L.), P-Fertilizers, Phosphorus (P) and Cadmium (Cd)

\section{Introduction}

Potato (Solanum tuberosum L.) is the fourth largest food crop after wheat, rice and corn. The presence of a variety of vitamins, especially vitamin $\mathrm{C}$, along with other essential minerals and proteins in potatoes, has made its consumption as a valuable food in the world, so that $2.5 \%$ of the daily energy of the world population is provided by potatoes. The per capita consumption of potatoes in the world is 100 and in Iran $45 \mathrm{~kg}$ per year and its average yield in the world is 40 and in Iran is 30 tons per hectare [1].

Cadmium is a heavy metal that its presence in the ecosystem is very dangerous for living organisms [2]. Absorption of this element by the plant leads to damage such as destruction of the nucleus, inhibition of the activity of some enzymes, necrosis and yellowing of leaves, reduced root and stem growth, reduced water absorption, reduced chlorophyll and carotenoids and inhibition of opening the stomata [3]. Cadmium is also a threat to human health, it is easily absorbed by the human digestive tract. $50 \%$ of the cadmium absorbed in the body, accumulates in the liver and kidneys and its half-life in the human body is between 10 and 30 years [4]. Toxic effects of cadmium on human include destruction of kidneys and liver tissue, carcinogenesis and emphysema [5].

Samavat et al. [6] reported that the consumption of phosphate fertilizers by farmers in the paddy fields of the north of the Iran increased the amount of soil cadmium by $15.5 \%$ in two years, which in turn caused contamination of rice. Preliminary studies on the concentration of cadmium in pistachios and dates have shown its amount to be equal to 0.48 and $0.12 \mathrm{mg} \mathrm{kg}^{-1}$ dry matter, respectively. Bybordi and Malakouti [7] reported that the highest cadmium concentration was measured if $150 \mathrm{~kg} \mathrm{ha}^{-1} \mathrm{P}$ was applied without zinc $(\mathrm{Zn})$. The results of these researchers showed that adding zinc to the soil reduced the concentration of cadmium in the tubers. The highest amount of phosphorus in the tubers was measured at 150 $\mathrm{kg} \mathrm{ha}^{-1}$ without the use of zinc. Asbaghian et al. [8] whose worked on a research on the effect of Zinc fertilizers on the cadmium concentration in potato tubers, concluded that there was a significant difference $(\mathrm{p}<0.01)$ between $\mathrm{Cd}$ concentration in control treatment and treatments in which $\mathrm{Zn}$-fertilizers have been used. The maximum Cd concentration has observed in control treatment with $0.13 \mathrm{mg} \mathrm{kg}^{-1}$ fresh weight and the minimum has obtained from SSOP $+\mathrm{Zn}$ chelate treatment by $0.01 \mathrm{mg} \mathrm{kg}^{-1}$ fresh weight. The maximum acceptable concentration of $\mathrm{Cd}$ in peeled potatoes according to the standard of 
the National Standard Organization of Iran and other international organizations is $0.10 \mathrm{mg} \mathrm{kg}^{-1}$ fresh weight of the plant [8]. Rahmani [9] in the study of the long-term effect of phosphate fertilizers on soil and plant cadmium concentration and environmental hazards in some areas of Isfahan province contaminated with cadmium metal showed that the concentration of soil cadmium in potato cultivated lands was in the range of 0 to $4 \mathrm{mg} \mathrm{kg}^{-1}$ and with an average of $1.98 \mathrm{mg}$ $\mathrm{kg}^{-1}$ of dry soil. In this study, the concentration of cadmium in potato tubers and during five consecutive years of cultivation was reported to be 0 to $12.3 \mathrm{mg} \mathrm{kg}^{-1} \mathrm{dry}$ matter. Due to the acceptable concentration of cadmium in potato crop $\left(0.20 \mathrm{mg} \mathrm{kg}^{-1}\right.$ fresh weight), the amount of cadmium accumulated in the potato tuber of the Daran region was more than threshold level and there is possibility of contamination and complication of cadmium in the plant, livestock and human body. McLaughlin et al. [10] reported that with the application of 200 $\mathrm{kg} \mathrm{ha}^{-1}$ of phosphorus fertilizer $\left(30 \mathrm{mg} \mathrm{kg}^{-1}\right.$ ) per year in the potato field, $6 \mathrm{~g} \mathrm{ha}^{-1}$ of cadmium enters the soil. The amount of cadmium in potato tubers ranged from 0.50 to $30 \mathrm{mg} \mathrm{kg}^{-1}$. The amount of cadmium entering the soil by phosphate fertilizers was from 8.2 to 40 and the amount of cadmium leaving by tubers was from 0.80 to 6.9 $\mathrm{g} \mathrm{ha}^{-1}$. The reduction of cadmium concentration in tubers by $25-50 \%$ due to the zinc fertilizer's application, also will be affected by the type of fertilizer, factors such as soil $\mathrm{pH}$, soil texture, soil organic matter, type of soil clay and also the plant variety. Therefore, the aim of this study was to investigate the effect of different sources of phosphate fertilizers on the accumulation of cadmium in potato tubers.

\section{Materials and Methods}

This experiment was performed in potato fields of Dehgolan city located in Kurdistan province, Iran. After selecting the desired land for the experiment, sampling was done randomly and mixed samples were prepared. The soil samples were air-dried and passed through a $2 \mathrm{~mm}$ sieve to analyze some physical and chemical properties. This experiment was performed in a randomized complete block design with four treatments and three replications (blocks). The first treatment included the control treatment in which the optimal application of fertilizers was observed based on the results of soil analysis except for phosphate fertilizer; The second treatment included control treatment in addition to Rock Phosphate (RP); The third treatment included control treatment in addition to supplying phosphorus from Simple Superphosphate Fertilizer (SSP) and the fourth treatment included control treatment in addition to supplying phosphorus from Triple Superphosphate Fertilizer (TSP). Potato tubers were harvested after the completion of the growing season (mid-November). After harvesting, the samples were thoroughly washed with distilled water. Each was then weighed separately and placed in separate bags. The samples were dried at $70^{\circ} \mathrm{C}$ in a ventilated oven and weighed again. The dried samples were thoroughly pulverized with an electric mill for chemical analysis and stored in special containers. Simultaneously, with the harvest of plant samples, soil samples were also taken from different plots, and after air drying, the samples were completely crushed and passed through a $2 \mathrm{~mm}$ sieve. They were then taken to a laboratory for chemical tests. Physical and chemical properties of soil samples including soil texture were measured by hydrometric method, organic carbon by Walkley and Black method, and calcium carbonate equivalent by reverse titration with hydrochloric acid [11]. Nitrogen concentration was measured by the Kjeldahl method, phosphorus by Olsen method by spectrophotometer, and potassium by flame photometer. In this study, a sample of water-to-soil suspension was prepared and the Electrical Conductivity $(\mathrm{EC})$ and soil reaction $(\mathrm{pH})$ of the extracts were determined using conductometers and $\mathrm{pH}$ meters, respectively [12]. In this study, DTPA extract (diethylenetriamine pentaacetic acid) in $0.01 \mathrm{M}$ calcium chloride base solution was used to measure cadmium and zinc absorbable elements in the soil. $10 \mathrm{~g}$ of soil was weighed and poured into $125 \mathrm{ml}$ Erlenmeyer. Then $20 \mathrm{ml}$ of DTPA solution was added. The lid was then closed and shaken for two hours with a shaker (GFL rotary shaker $145 \mathrm{rpm}$ ) and smoothed with Whatman 42 filter paper. Then the concentrations of zinc and cadmium in the extract were read by ICP-OES. Also in this study, the wet digestion method (digestion with a mixture of nitric acid, perchloric acid and sulfuric acid) was used to measure cadmium and zinc in the plant [13]. To measure the percentage of dry matter, several large, medium and small tubers were washed and dried with ordinary water and distilled water, respectively. After weighing, the tubers were cut into thin slices and placed in an oven at $75^{\circ} \mathrm{C}$ for 48 hours to dry completely. Then the dry weight of the samples was measured and the percentage of dry matter of tubers was calculated. SPSS 18 software was used to compare treatments and analyze variance. Relevant graphs and tables were drawn with Excel software and Duncan's multiple range test at the probability level of 0.01 and 0.05 was used to compare the means.

\section{Results and Discussion}

The results of some physical and chemical properties of soil before planting are presented in Table 1.

Table 2 presents the results of analysis of variance of the effect of different treatments of phosphate fertilizer on the concentration of phosphorus in the soil. The results of this table show that different sources of phosphate fertilizers have caused significant differences in the concentration of phosphorus in the soil and at a statistical level of $5 \%(\alpha=5 \%)$. Figure 1 shows the concentration of soil phosphorus in different treatments of phosphate fertilizers. According to this figure, different sources of phosphate fertilizers have caused significant differences in the concentration of phosphorus in the soil compared to the control treatment. So that the lowest concentration of phosphorus in the soil is related to the control treatment with a concentration of $5 \mathrm{mg} \mathrm{kg}^{-1}$ and the highest is related to the triple superphosphate treatment with a concentration of $16 \mathrm{mg} \mathrm{kg}^{-1}$.

Table 3 shows the results of analysis of variance of the effect of different treatments of phosphate fertilizer on the concentration of cadmium in the soil. According to the table, it can be seen that

Table 1: Physical and chemical analysis of the soil before planting.

\begin{tabular}{|c|c|c|c|c|c|c|}
\hline (Total N) (\%) & $\left(\mathrm{CaCO}_{3}\right)(\%)$ & $(E C)\left(\mathrm{dS} \mathrm{m} \mathrm{m}^{-1}\right)$ & (OC) (\%) & $\mathrm{pH}$ & Texture & Depth (cm) \\
\hline 0.12 & 13 & 1.5 & 0.8 & 7.4 & Clay Loam & $0-30$ \\
\hline (Cd) $\left(\mathrm{mg} \mathrm{kg}^{-1}\right)$ & (S) $\left(\mathrm{mg} \mathrm{kg}^{-1}\right)$ & (B) $\left(\mathrm{mg} \mathrm{kg}^{-1}\right)$ & $\left.(\mathrm{Zn})(\mathrm{mg} \mathrm{kg})^{-1}\right)$ & (K) $\left(\mathrm{mg} \mathrm{kg}^{-1}\right)$ & (P) $\left(\mathrm{mg} \mathrm{kg}^{-1}\right)$ & $(\mathrm{Fe})\left(\mathrm{mg} \mathrm{kg}^{-1}\right)$ \\
\hline 0.15 & 7 & 0.72 & 0.75 & 150 & 8 & 7.2 \\
\hline
\end{tabular}


Table 2: Analysis of variance for effect of phosphate fertilizers different treatments on the concentration of $\mathrm{P}$ in the soil.

\begin{tabular}{|c|c|c|}
\hline Source of Variation & df & Mean square \\
\hline Block & 2 & $5.813^{*}$ \\
\hline Treatment & 3 & $66^{*}$ \\
\hline Error & 6 & 0.813 \\
\hline Total & 12 & --- \\
\hline CV & --- & 21 \\
\hline
\end{tabular}

**, *: Show significant difference at $1 \%$ and $5 \%$, respectively; ns shows nonsignificant.

Table 3: Analysis of variance for effect of phosphate fertilizers different treatments on the concentration of $\mathrm{Cd}$ in the soil.

\begin{tabular}{|c|c|c|}
\hline Source of Variation & df & Mean square \\
\hline Block & 2 & $0.001^{\star *}$ \\
\hline Treatment & 3 & $0.025^{\star *}$ \\
\hline Error & 6 & 0.00012 \\
\hline Total & 12 & --- \\
\hline CV & --- & 20 \\
\hline
\end{tabular}

**, *: Show significant difference at $1 \%$ and $5 \%$, respectively; ns shows nonsignificant.

Table 4: Analysis of variance for effect of phosphate fertilizers different treatments on the potato tubers yield.

\begin{tabular}{|c|c|c|}
\hline Source of Variation & df & Mean square \\
\hline Block & 2 & $6.06^{\star}$ \\
\hline Treatment & 3 & $10.75^{\star}$ \\
\hline Error & 6 & 0.729 \\
\hline Total & 12 & --- \\
\hline CV & --- & 20 \\
\hline
\end{tabular}

**, *: Show significant difference at $1 \%$ and $5 \%$, respectively; ns shows nonsignificant.

Table 5: Analysis of variance for effect of phosphate fertilizers different treatments on the concentration of $\mathrm{P}$ in the potato tubers.

\begin{tabular}{|c|c|c|}
\hline Source of Variation & $\mathbf{d f}$ & Mean square \\
\hline Block & 2 & $0.001^{*}$ \\
\hline Treatment & 3 & $0.004^{*}$ \\
\hline Error & 6 & 9.79 \\
\hline Total & 12 & --- \\
\hline CV & --- & 21 \\
\hline
\end{tabular}

**, * Show significant difference at $1 \%$ and $5 \%$, respectively; ns shows nonsignificant.

different sources of phosphate fertilizers have caused significant differences in the concentration of cadmium in the soil and at a statistical level of $1 \%(\alpha=1 \%)$.

Figure 2 also shows the concentration of soil cadmium in different treatments of phosphate fertilizers. According to this figure, different sources of phosphate fertilizers have caused significant differences in the concentration of cadmium in the soil compared to the control treatment. The results show that the lowest concentration of cadmium in the soil is related to the control treatment with a concentration of $0.15 \mathrm{mg} \mathrm{kg}^{-1}$ and the highest is related to the triple superphosphate treatment with a concentration of $0.35 \mathrm{mg} \mathrm{kg}^{-1}$.

Table 4 presents the results of analysis of variance of the effect
Table 6: Analysis of variance for effect of phosphate fertilizers different treatments on the accumulation of $\mathrm{Cd}$ in the potato tubers.

\begin{tabular}{|c|c|c|}
\hline Source of Variation & df & Mean square \\
\hline Block & 2 & $0.002^{*}$ \\
\hline Treatment & 3 & $0.025^{\star}$ \\
\hline Error & 6 & 0.00019 \\
\hline Total & 12 & --- \\
\hline CV & --- & 18 \\
\hline
\end{tabular}

**, *: Show significant difference at $1 \%$ and $5 \%$, respectively; ns shows nonsignificant.

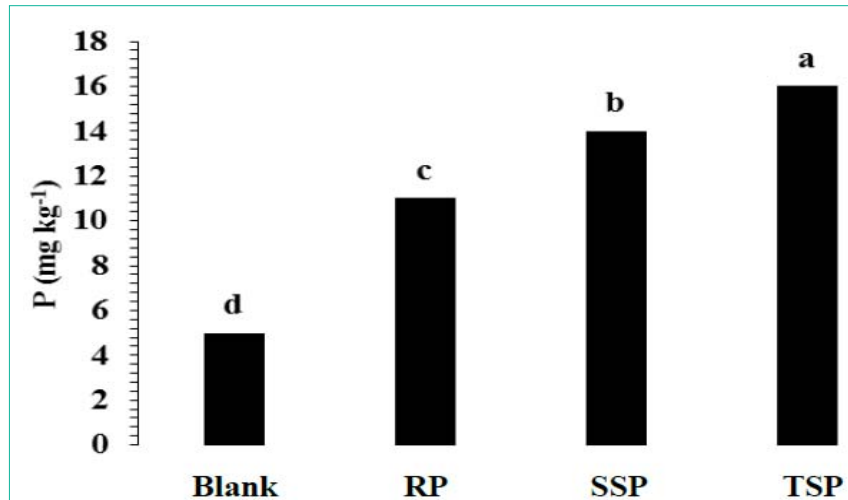

Figure 1: The concentration of $\mathrm{P}$ in the soil at phosphate fertilizers different treatment.

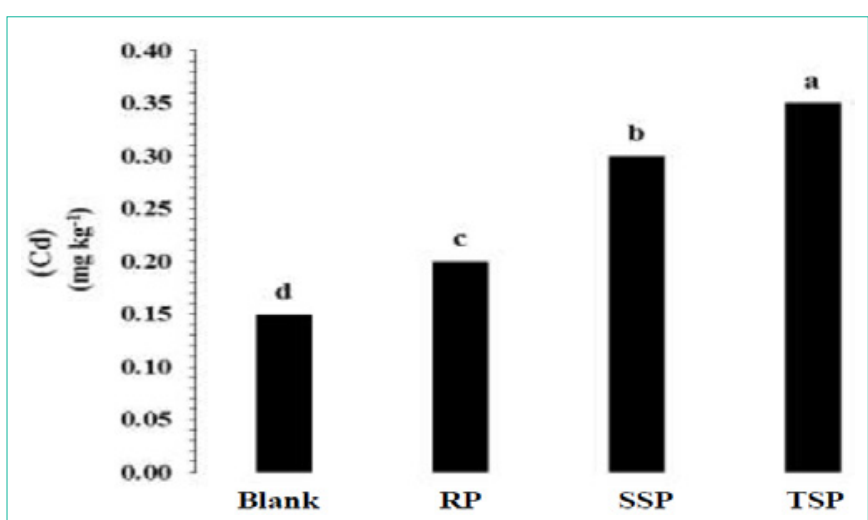

Figure 2: The concentration of $\mathrm{Cd}$ in the soil at phosphate fertilizers different treatments.

of different treatments of phosphate fertilizers on the yield of potato tubers. As can be seen in this table, different sources of phosphate fertilizers caused a statistically significant difference at the level of $5 \%(\alpha=5 \%)$ in the yield of potato tubers compared to the control treatment.

Figure 3 also shows the hectare yield of potato tubers in different treatments of phosphate fertilizers. As can be seen in this figure, different sources of phosphate fertilizers have caused significant differences in the yield of potato tubers compared to the control treatment. According to this figure, the lowest yield of potato tubers is related to control treatment with 33 tons per hectare and the highest amount is related to phosphate soil treatment with 37 tons per hectare. The results also show that there is no significant difference between the yields of potato tubers resulting from different treatments of 


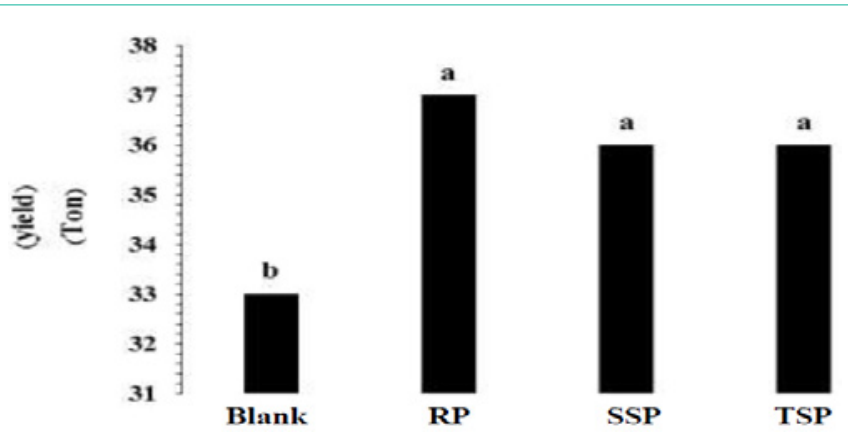

Figure 3: The potato tubers yield at phosphate fertilizers different treatments.

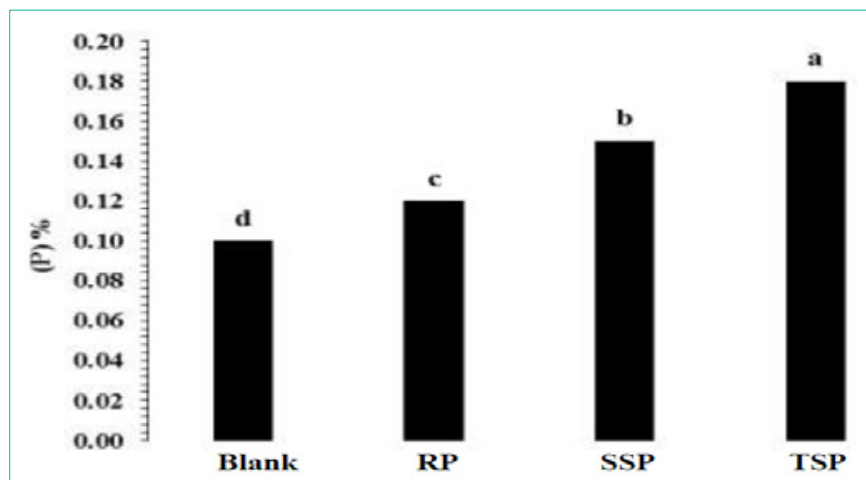

Figure 4: The concentration of $\mathrm{P}$ in potato tubers at phosphate fertilizers different treatments.

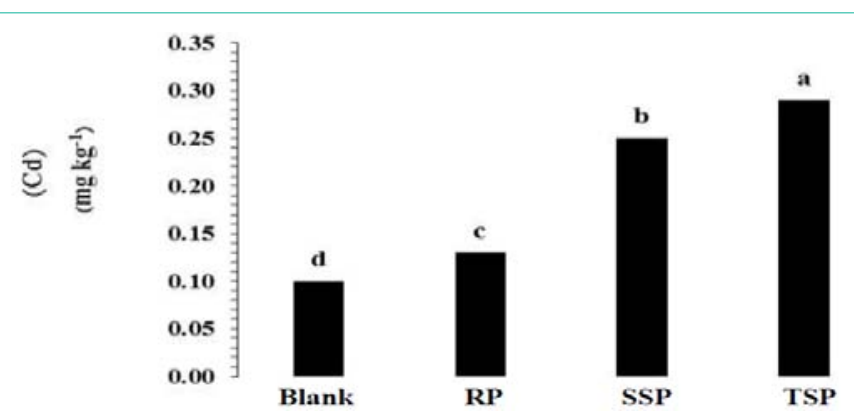

Figure 5: The concentration of $\mathrm{Cd}$ in potato tubers at phosphate fertilizers different treatments.

phosphate fertilizers.

Table 5 presents the results of analysis of variance of the effect of different treatments of phosphate fertilizers on the phosphorus concentration of potato tubers. The results of this table show that different sources of phosphate fertilizers cause statistically significant differences at level of $5 \%(\alpha=5 \%)$ in the phosphorus concentration of potato tubers.

Figure 4 shows the phosphorus concentration of potato tubers in different treatments of phosphate fertilizers. Due to this form, different sources of phosphate fertilizers have caused significant differences in the phosphorus concentration of potato tubers compared to the control treatment. The results show that the lowest concentration of phosphorus in potato tubers is related to the control treatment with a concentration of $0.10 \%$ and the highest is related to the triple superphosphate treatment with a concentration of $0.18 \%$.
Table 6 shows the results of analysis of variance of the effect of different treatments of phosphate fertilizers on the cadmium concentration of potato tubers. According to this table, different sources of phosphate fertilizers have caused a statistically significant difference at the level of $5 \%$ in the cadmium concentration of potato tubers.

Figure 5 also shows the cadmium concentration of potato tubers in different treatments of phosphate fertilizers.

As this figure shows, different sources of phosphate fertilizers have caused significant differences in the cadmium concentration of potato tubers compared to the control treatment $(0.10 \mathrm{mg} \mathrm{kg}$ ${ }^{1}$ ). Among the various sources of phosphate fertilizers, the lowest concentration of cadmium in potato tubers was related to rock phosphate treatment with a concentration of 0.13 and the highest was related to triple superphosphate treatment with a concentration of $0.29 \mathrm{mg} \mathrm{kg}^{-1}$. Also, the concentration of cadmium in potato tubers in simple superphosphate treatment was $0.25 \mathrm{mg} \mathrm{kg}^{-1}$.

The results showed that there was no significant difference between the amounts of yield in different treatments of phosphate fertilizer. Decreased yield in simple and triple superphosphate treatments may be due to the negative interaction between phosphorus and zinc or between cadmium and zinc, which ultimately reduces the uptake of zinc and thus the yield of potato tubers [8]. Dadkhah [14] reported that the highest yield of potato tubers was obtained with the application of $80 \mathrm{~kg} \mathrm{ha}^{-1}$ of zinc sulfate and the lowest yield was obtained with the non-application of zinc sulfate. The results showed that with increasing the amount of cadmium in the soil, the concentration of this element in potato tubers increased significantly. According to Figure 5, the amount of cadmium in potato tubers in the control treatment and rock phosphate treatment is less than the allowable limit and in simple superphosphate and triple superphosphate treatments is higher than the acceptable limit (the acceptable limit of cadmium in the tuber Potatoes are equal to $0.20 \mathrm{mg} \mathrm{kg}^{-1}$ [15]. Due to the low mobility of cadmium in the plant, most of this element accumulates in the roots of the plant (especially the tubers) and small amounts of it are transferred to aerial organs such as leaves [8]. According to the results, with increasing the concentration of cadmium in the tubers, the concentration of zinc decreased, which is due to the negative interaction with cadmium. According to Malakouti [4], zinc and cadmium due to ionic similarity, have a negative interaction in the soil during plant uptake, so that increasing the concentration of zinc in the soil reduces the uptake of cadmium through the plant due to competition between zinc and cadmium. Therefore, in this study, in the almost constant concentration of zinc in the soil, in the triple superphosphate treatment, the highest and in the control treatment, the lowest amount of cadmium concentration was observed in the tubers. Also, the highest concentration of zinc in the tubers was related to the control treatment and the lowest concentration was in the triple superphosphate treatment. Koleli et al. [16] reported that zinc application usually reduces the uptake and accumulation of cadmium in plants due to competition with cadmium. Nan et al. [17] also reported that zinc consumption decreased cadmium concentrations in wheat and corn and the amount of this reduction was higher in wheat. The researchers also showed that cadmium accumulation is higher in zinc-deficient soils. According to the results, with increasing the concentration of phosphorus in the 
tubers, the concentration of cadmium also increased, which may be due to the negative interaction of phosphorus with zinc. Due to this negative interaction, the uptake of zinc decreased and since cadmium and zinc also compete for uptake, the uptake of cadmium increased. McLaughlin et al. [10] reported that by applying $80 \mathrm{~kg} \mathrm{ha}^{-1}$ of phosphorus (assuming a cadmium concentration of $250 \mathrm{mg} \mathrm{kg}^{-1}$ ), $20 \mathrm{~g} \mathrm{ha}^{-1}$ of cadmium enters the soil on a potato field.

\section{Conclusion}

In general, according to the results, it is inferred that different sources of phosphate fertilizers cause the accumulation of different amounts of cadmium in potato tubers. In addition to the type of phosphate source, the interaction of phosphorus and zinc is also effective in the accumulation of cadmium in potato tubers. Due to the fact that the type of phosphate source did not have much effect on the yield of potato tubers, so in terms of quality (increasing dry matter percentage and decreasing cadmium concentration), rock phosphate treatment resulted in the production of higher quality tubers. The results showed that the consumption of phosphorus from triple superphosphate sources and even simple superphosphate with a content of more than $10 \mathrm{mg} \mathrm{kg}^{-1}$ of cadmium, led to the unauthorized accumulation of cadmium in potato tubers. Therefore, with the optimal use of phosphate fertilizers and fertilizers containing zinc (especially zinc sulfate), the concentration of cadmium (as a contaminant) can be reduced and the concentration of zinc (as an essential element) can be increased. Therefore, it is recommended that the use of chemical fertilizers, especially phosphate fertilizers, be done through the results of soil analysis. In addition, the amount of phosphate fertilizers used, taking into account the total phosphorus and its critical limit in arable soils, is saved and the entry of phosphate fertilizers or rock phosphate containing more than $15 \mathrm{mg} \mathrm{kg}^{-1}$ of cadmium is prevented. Also, due to zinc deficiency in agricultural lands and crops in the Iran, it is suggested that more research be done on the effect of phosphate fertilizers in aggravating the deficiency of this element.

\section{References}

1. Rezai A and Soltani A. Introduction to potato production. Jahad Pub. Co., Mashhad Univ., Iran. 1996.

2. Kabata-Pendias A and Pendias H. Trace Elements in Soils and Plants. Florida: Boca Raton. 2001.

3. Sanita di Toppi L and Gabbrielli R. Response to cadmium in higher plants. J. Environ. Exp. Bot. 1999; 41: 105-130.
4. Malakouti MJ. The role of balanced fertilization on increasing yield and producing healthy agricultural products: Determining the amount, type and time of fertilization to achieve relative self-sufficiency, food security and increase farmer's incomes. $4^{\text {th }}$ publication. Farmer's house, 104, Mobaleghan publication, 458 pages, Tehran. Iran. (In Persian). 2018

5. Lin $\mathrm{J}$ and Schorr M. A challenge for the phosphate industry: Cd removal phosphorous and potassium industry. 1977; 208: 27-31.

6. Samavat S, Bybordi A, Malakouti MJ and MM Tehrani. Acceptable level of cadmium in fertilizers and agricultural crops. Soil and Water Research Institute, Technical Bulletion, Tehran: Sana publication. 2005.

7. Bybordi A, Malakouti MJ. Effect of different levels of phosphorus and zinc on cadmium concentrations in potato cultivars in Sarab (East Azerbaijan), Tabriz, Iran. 2000.

8. Asbaghian Namini SK, Malakouti MJ, Ghavidel A. The effect of Zinc chelate and Potassium sulfate topdressing on alleviating the Cadmium (Cd) and Nitrate $\left(\mathrm{NO}_{3}{ }^{-}\right)$toxicity in potato tubers of Ardabil province, Iran. J Agric Sc Food Technol. 2021; 7: 034-042.

9. Rahmani HR. Long-term effect of phosphorus fertilizers on the level of cadmium in soil \& plant and environmental hazards posed by it in some of the affected areas of Isfahan (Report). Soil and Water Research Institute, Esfahan, Iran. 2009.

10. McLaughlin MJ, Tiller KG and Hamblin A. Managing cadmium contamination of agricultural land. In: Fertilizers as a source of cadmium. Organization for Economic Co-Operation and Development (OECD), Paris. 1996; 189-217.

11. Margesin R, Schinner F. Manual for soil analysis-monitoring and assessing soil bioremediation. Springer Science \& Business Media. 2005.

12. Page AL, Miller RH and Keeney DR. Method of soil Analysis, Part 2, Chemical and Microbiological properties. American Society of Agronomy, Inc. Soil Science of American, Inc. Madison, Wisconsin, USA. 1982; 1159

13. Gupta PK. Soil, plant, water and fertilizer analysis. Agrobios, New Delhi, India. 2000: 438

14. Dadkhah $\mathrm{H}$. The effect of different levels of zinc and boron on yield and dry matter in potato. MSc thesis, Tarbiat Modares University, Tehran, Iran. 2012.

15. FAO \& WHO. Working document for information and use in discussions related to contaminants and toxins in the GSCTFF. Joint FAO/WHO food standards programme codex committee on contaminants in foods, Fifth Session, The Hague, The Netherlands. 2010

16. Koleli N. Eker S and Cakmak I. Effect of zinc fertilization on cadmium toxicity in durum and bread wheat grown in zinc-deficient soil Environmental Pollution. 2004; 131: 453-459.

17. Nan Z. Li J. Zhang J. and Cheng G. Cadmium-zinc and their transfer in soilcrop system under actual field conditions. Sci. Total Environ. 2002; 285: $187-$ 195. 